\title{
Effect of Level of Metabolizable Protein on Milk Production and Nitrogen Utilization in Lactating Dairy Cows ${ }^{1}$
}

\author{
C. Wang, ${ }^{*}$ J. X. Liu, ${ }^{* 2}$ Z. P. Yuan, ${ }^{*}$ Y. M. Wu, ${ }^{*}$ S. W. Zhai, ${ }^{*}$ and H. W. Ye† \\ *Institute of Dairy Science, Zhejiang University, Hangzhou 310029, People's Republic of China \\ †Hangzhou Zhengxing Animal Industry Company, Hangzhou 311301, People's Republic of China
}

\begin{abstract}
The objective of this study was to investigate the effects of the level of metabolizable protein (MP) on milk production and nitrogen utilization in Chinese Holstein dairy cows. Forty multiparous dairy cows (body weight $=590 \mathrm{~kg}$; days in milk $=135$; average milk yield $=30.2 \mathrm{~kg} / \mathrm{d}$ ) were assigned to treatments randomly within groups based on days in milk and milk production. Animals were offered diets with different levels of MP: $8.3 \%(\operatorname{diet} A), 8.9 \%(\operatorname{diet} B), 9.7 \%(\operatorname{diet} C)$, and $10.4 \%$ (diet D) of dry matter. The MP level in $\operatorname{diet} \mathrm{A}$ was designed to meet the current Chinese National Station of Animal Production and Health guidelines, whereas that in diet D was based on the National Research Council (2001) model. The experiment lasted for 7 wk. Milk yield and milk composition (fat, protein, and lactose) were recorded, and urea nitrogen concentrations in serum, urine, and milk were measured during the experiment. Milk yield and milk protein percentage increased as the MP increased up to $9.7 \%$ of dry matter, and then leveled off. Concentrations of nitrogen in urine, serum, and milk increased linearly as the amount of MP was increased, indicating decreased efficiency of nitrogen utilization. Milk lactose percentage and total solids percentage showed no significant differences among the 4 diets. We concluded that the optimal dietary MP level was at $9.6 \%$ of dry matter for Chinese Holstein dairy cows producing $30 \mathrm{~kg}$ of milk per day.

Key words: metabolizable protein, milk production, nitrogen utilization, lactating cows
\end{abstract}

\section{INTRODUCTION}

The agricultural community is under strong pressure from the public to reduce avoidable losses of $\mathrm{N}$ all over the world. With increasing environmental constraints,

\footnotetext{
Received March 9, 2006.

Accepted February 18, 2007.

${ }^{1}$ Research supported in part by Ministry of Science and Technology and by Ministry of Agriculture, China.

${ }^{2}$ Corresponding author: liujx@zju.edu.cn
}

research is being directed toward improving the efficiency of $\mathrm{N}$ utilization by lactating dairy cows while optimizing milk production and composition.

Recent studies have shown that altering the supply of RUP alone cannot explain variations in milk production responses (Santos et al., 1998; NRC, 2001). Together, these data clearly demonstrate that the supply of $\mathrm{CP}$ or RUP in dairy rations should no longer be used alone to estimate the protein delivered to animals. A more precise system of MP was used to supersede the use of the CP or RUP system (NRC, 2001). When the earlier data were reevaluated using this approach, it was clear that changes in milk production were related to the MP rather than to either CP or RUP (Metcalf et al., 1996; Wright et al., 1998).

Although the protein systems for dairy cattle in different feeding standards [Agricultural and Food Research Council (AFRC), 1993; NRC, 2001] are based on the requirements of rumen microbes and the host animals, comparison of these standards has revealed that the MP recommendation for midlactation cows producing up to $30 \mathrm{~kg} / \mathrm{d}$ varies greatly among different recommendations. These differences are attributed to the requirements for maintenance and the efficiency of utilization of absorbed AA for milk protein synthesis. Furthermore, differences in requirements for maintenance between lactation and nonlactation or low and high dietary protein were not considered in the Chinese National Station of Animal Production and Health (CNSAPH) (2000) and AFRC (1993) .

The MP requirement may be met by providing both RDP and RUP. Rumen microbial protein, RUP, and endogenous protein contribute AA to the small intestines, with microbial protein accounting for the majority of the total AA flow (Clark et al., 1992; Santos and Huber, 1995). Therefore, supplementation of the MP is a direct way to increase the AA entering into the duodenum. However, overfeeding of protein may result in excessive excretion of urinary $\mathrm{N}$, the most environmentally labile form of excreted N (Varel et al., 1999). There are reports that approximately $70 \%$ of the excreted $\mathrm{N}$ can be lost into the environment through volatilization, leaching, and runoff, contributing to environ- 
mental pollution (Tamminga, 1992; Van Horn et al., 1994; Huston et al., 1998).

The objective of this study was to determine the effects of the dietary MP level on milk production and on $\mathrm{N}$ utilization and excretion in Chinese Holstein dairy cows, especially in milk protein production efficiency in comparison with the NRC (2001) recommendations.

\section{MATERIALS AND METHODS}

\section{Animals, Diets, and Experiment Design}

Forty multiparous Chinese Holstein cows in midlactation $[\mathrm{BW}=590 \mathrm{~kg}$ (SD 15); average DIM = 135 (SD 7 ), milk yield $=30.2 \mathrm{~kg}(\mathrm{SD} 2.69) / \mathrm{d}$ )] were used in a completely randomized block design. Animals were divided into 10 groups according to DIM and milk production and were assigned to treatments randomly within groups to evaluate the response to dietary MP. Cows were housed in a tie-stall barn and were fed and milked at 0600,1430 , and $2100 \mathrm{~h}$. All animals had free access to drinking water. The experiment lasted for $7 \mathrm{wk}$ from early April to the end of May 2005, following a week of adaptation to the diets.

Four diets (A, B, C, and D) were formulated to contain 4 levels of MP $(8.2,8.9,9.7$, and $10.3 \%$ of DM), with CP contents of $12,13,14$, and $15 \%$ of $\mathrm{DM}$, respectively. The content of $\mathrm{NE}_{\mathrm{L}}$ was $1.4 \mathrm{Mcal} / \mathrm{kg}$ for all diets, with the ratio of concentrate to forage at 45:55 (DM basis), and alfalfa hay and corn silage were the main sources of forage. The ingredients and composition of the experimental diets are presented in Table 1. Diet A was designed to meet MP requirements for lactating cows producing $30 \mathrm{~kg}$ of milk according to the CNSAPH (2000), whereas the MP level in diet $\mathrm{D}$ was based on the NRC (2001) model. Diets B and C were formulated to contain midlevels of dietary MP. Feed was offered to result in $10 \%$ orts.

\section{Sampling, Measurement, and Analyses}

Feeds offered to and refused by individual cows (3 for each treatment) were weighed for 2 consecutive days every second week throughout the trial. The forage and concentrates were sampled weekly. Ort samples were collected weekly and composited by animal (3 for each treatment) in proportion to the wet weight of orts from each specific day. All samples were immediately dried in a forced-air oven at $60^{\circ} \mathrm{C}$ for $48 \mathrm{~h}$ and stored in sealed plastic containers at room temperature until analyzed. In preparation for analyses, dried forages and concentrates were ground first through a 2-mm screen (Wiley mill, Arthur H. Thomas, Philadelphia, PA), then through a 1-mm screen in a Cyclotec mill (Tecator 1093, Tecator, Hoganas, Sweden). Dry matter was deter-
Table 1. Ingredients and composition of the experimental diets

\begin{tabular}{lrrrr}
\hline Item & Diet A & Diet B & Diet C & Diet D \\
\hline Ingredient, \% of DM & & & & \\
Alfalfa hay ${ }^{1}$ & 22 & 22 & 22 & \multicolumn{1}{c}{22} \\
Corn silage ${ }^{2}$ & 33 & 33 & 33 & 33 \\
Ground corn grain & 27.6 & 24.5 & 21.3 & 17.0 \\
Soybean meal, 42.5\% CP & 1.7 & 2.5 & 5.5 & 6.6 \\
Cottonseed & 2.7 & 3.0 & 2.7 & 2.6 \\
Cottonseed meal & 3.2 & 3.6 & 3.6 & 5.1 \\
Wheat bran & 3.4 & 3.7 & 3.4 & 3.0 \\
Rapeseed meal & 1.5 & 2.8 & 3.9 & 5.8 \\
Dicalcium phosphate & 1.3 & 1.3 & 1.0 & 1.3 \\
Limestone & 0.9 & 0.9 & 0.9 & 0.9 \\
Sodium bicarbonate & 0.7 & 0.7 & 0.7 & 0.7 \\
Salt & 1.0 & 1.0 & 1.0 & 1.0 \\
Premix & 1.0 & 1.0 & 1.0 & 1.0 \\
Composition & & & & \\
DM, \% & 50.5 & 50.7 & 50.8 & 50.9 \\
CP, \% of DM & 11.9 & 13.0 & 14.2 & 15.4 \\
RUP, \% of DM & 4.5 & 5.4 & 6.6 & 7.9 \\
RDP ${ }^{4} \%$ of DM & 7.4 & 7.6 & 7.6 & 7.5 \\
MP, \% of DM & 8.3 & 8.9 & 9.7 & 10.4 \\
NDF, ${ }^{4} \%$ of DM & 41.0 & 41.5 & 41.8 & 42.0 \\
NE ${ }_{\mathrm{L}}^{4}{ }^{4}$ Mcal/kg of DM & 1.4 & 1.4 & 1.4 & 1.4 \\
\hline
\end{tabular}

${ }^{1}$ Alfalfa hay contained $90 \%$ of DM, $18.4 \% \mathrm{CP}, 10.9 \% \mathrm{RDP}$ and $60.3 \%$ $\mathrm{NDF}$, and $44.7 \% \mathrm{ADF}$ on a DM basis.

${ }^{2}$ Corn silage contained $22.7 \% \mathrm{DM}, 7 \% \mathrm{CP}, 4.6 \% \mathrm{RDP}, 67.2 \% \mathrm{NDF}$ and $41.0 \% \mathrm{ADF}$ on $\mathrm{DM}$ basis.

${ }^{3}$ Formulated to provide (per kg of DM) 1,000,000 IU of vitamin A, $200,000 \mathrm{IU}$ of vitamin D, 1,250 IU of vitamin E, 14,000 $\mathrm{mg}$ of $\mathrm{Zn}$, $100 \mathrm{mg}$ of Se, $180 \mathrm{mg}$ of I, 3,000 mg of Fe, $40 \mathrm{mg}$ of Co, 3,000 mg of $\mathrm{Mn}$, and 3,000 $\mathrm{mg}$ of $\mathrm{Cu}$.

${ }^{4}$ Calculated based on individual feedstuffs in the Chinese National Station of Animal Production and Health (2000) guidelines.

mined by drying a subsample at $100^{\circ} \mathrm{C}$ for $24 \mathrm{~h}$. All samples were analyzed for NDF (Van Soest et al., 1991) and total N (method 988.05; AOAC, 1990).

Milk sampling devices (Waikato Milking Systems NZ Ltd., Waikato, Hamilton, New Zealand) were attached to the milking machine to measure milk weight and collect samples. Milk production was recorded for all 3 milking times. Two 50-mL aliquots of milk were collected weekly at each milking, proportional to yield (4: 3: 3, composite). One aliquot containing Bronopol (milk preservative, D\&F Control Systems, San Ramon, CA) was stored at $4^{\circ} \mathrm{C}$ for later analysis of fat, protein, and lactose by infrared analysis (Laporte and Paquin, 1999) with a 4-channel spectrophotometer (Milk-O-Scan, Foss Electric, Hillerød, Denmark). The second aliquot without Bronopol was stored at $-20^{\circ} \mathrm{C}$ and thawed for analysis after the end of the experiment. The samples were deproteinized with $4 \mathrm{~mL}$ of cold TCA (25\%), allowed to stand for $5 \mathrm{~min}$, and then centrifuged at $3000 \times g$ for 20 min at $4^{\circ} \mathrm{C}$. The clear supernatant was pipetted carefully through the solidified fat layer and analyzed for MUN using the diacetyl monoxime-binding assay (Rahmatullah and Boyd, 1980). 
Table 2. Effects of MP offered to dairy cows in midlactation on DMI, milk yield, and milk composition

\begin{tabular}{lcccccrr}
\hline & & & & & & $P^{1}$ \\
\cline { 5 - 7 } Item & Diet A & Diet B & Diet C & Diet D & SE & L & Q \\
\hline Intake, kg/d & & & & & & & \\
DM & 21.1 & 21.4 & 21.5 & 20.8 & 0.24 & 0.64 & 0.17 \\
MP & $1.75^{\mathrm{c}}$ & $1.91^{\mathrm{b}}$ & $2.09^{\mathrm{a}}$ & $2.16^{\mathrm{a}}$ & 0.024 & $<0.01$ & 0.22 \\
Milk production, kg/d & & & & & & & \\
Milk & $27.2^{\mathrm{b}}$ & $28.3^{\mathrm{ab}}$ & $29.4^{\mathrm{a}}$ & $29.8^{\mathrm{a}}$ & 0.61 & $<0.01$ & 0.48 \\
4\% FCM & $25.8^{\mathrm{b}}$ & $27.7^{\mathrm{a}}$ & $28.0^{\mathrm{a}}$ & $27.1^{\mathrm{ab}}$ & 0.63 & 0.24 & $<0.01$ \\
Milk protein & $0.82^{\mathrm{b}}$ & $0.89^{\mathrm{a}}$ & $0.92^{\mathrm{a}}$ & $0.89^{\mathrm{a}}$ & 0.100 & 0.02 & $<0.01$ \\
Milk composition, \% & & & & & & & \\
Protein & $3.03^{\mathrm{b}}$ & $3.11^{\mathrm{a}}$ & $3.08^{\mathrm{ab}}$ & $3.03^{\mathrm{b}}$ & 0.120 & 0.70 & $<0.01$ \\
Fat & $3.61^{\mathrm{b}}$ & $3.82^{\mathrm{a}}$ & $3.56^{\mathrm{b}}$ & $3.45^{\mathrm{b}}$ & 0.214 & 0.30 & $<0.01$ \\
Lactose & $4.51^{\mathrm{b}}$ & $4.66^{\mathrm{a}}$ & $4.59^{\mathrm{a}}$ & $4.65^{\mathrm{a}}$ & 0.112 & $<0.01$ & 0.03 \\
TS & $12.04^{\mathrm{b}}$ & $12.46^{\mathrm{a}}$ & $12.11^{\mathrm{b}}$ & $11.90^{\mathrm{b}}$ & 0.204 & 0.60 & $<0.01$ \\
SNF & $8.27^{\mathrm{c}}$ & $8.50^{\mathrm{a}}$ & $8.40^{\mathrm{b}}$ & $8.37^{\mathrm{b}}$ & 0.120 & 0.08 & $<0.01$ \\
\hline
\end{tabular}

${ }^{\mathrm{a}-\mathrm{c}}$ Means within same row with different superscripts differ $(P<0.05)$.

${ }^{1} \mathrm{~L}=$ linear; $\mathrm{Q}=$ quadratic.

Blood samples $(10 \mathrm{~mL})$ were collected from the coccygeal vein at approximately $5 \mathrm{~h}$ after feeding on the first day of the first, third, fifth, and seventh weeks, and then centrifuged at $3,000 \times g$ for 15 min to harvest serum. Serum was frozen at $-10^{\circ} \mathrm{C}$ and later thawed for analysis of blood urea N (Rahmatullah and Boyd, 1980).

Spot urine samples (Valadares, et al., 1999) from 20 cows (5 for each treatment) were collected approximately $5 \mathrm{~h}$ after feeding on the first day of the first, third, fifth, and seventh weeks. Urine samples were acidified immediately after collection by diluting 1 vol of urine with $4 \mathrm{vol}$ of $0.072 \mathrm{~N} \mathrm{H}_{2} \mathrm{SO}_{4}$ and stored at $-20^{\circ} \mathrm{C}$. Later, urine samples were thawed at room temperature and analyzed for urinary urea N (Rahmatullah and Boyd, 1980).

\section{Statistical Analysis}

Feed intake, milk components, and urea $\mathrm{N}$ from milk, blood, and urine were analyzed using the REPEATED procedure of the SAS software system (SAS Institute, 2000), with week as a repeated measurement and the first-day data of trial as a covariant in the ANOVA. Type III sums of squares were used to determine whether treatment effects were significant. Tukey's multiple range test was used to examine the significance of differences between means. Treatments were evaluated for linear and quadratic effects using polynomial contrasts (orthogonal polynomial contrasts). The linear component indicated that the difference between the first and last levels was significant, whereas the quadratic component indicated the lack of fit of the intermediary level for a linear relationship (Gill, 1978). Probability values of $P<0.05$ were used to define statistically significant results, with statistical trends being defined at $P<0.10$.
Two cows fed diet D could not be used for this trial, because they became ill in midexperiment. Therefore, all data collected from these 2 cows were deleted from the statistical analysis (i.e., $\mathrm{n}=10$ for $\operatorname{diets} \mathrm{A}, \mathrm{B}$, and $\mathrm{C}$, and $\mathrm{n}=8$ for $\operatorname{diet} \mathrm{D}$ ).

\section{RESULTS AND DISCUSSION}

\section{Feed Intake}

The MP intakes were slightly higher than designed, but the MP percentages were similar to those presumed for all diets (Table 2). There were no significant dietary effects on daily DMI except for a decreased trend in diet D. The same results were indicated by Groff and Wu (2005) and Davidson et al. (2003). No significant difference was observed in energy intake between the $4 \operatorname{diets}(P>0.05)$. Daily MP intake was significantly higher $(P<0.05)$ for cows consuming diets $\mathrm{C}$ and $\mathrm{D}$ than for those on the other 2 treatments $(P<0.05)$, with no significant difference between diets $\mathrm{C}$ and $\mathrm{D}$ $(P>0.05)$.

\section{Milk Yield and Composition}

Data for milk yield and composition are presented in Table 2. Increasing dietary MP resulted in an increased milk yield, $4 \% \mathrm{FCM}$ and milk protein, and protein percentage, but in decreased milk fat percentage. Yields of FCM and milk protein changed in linear and quadratic ways, and percentages of milk lactose and total solids did not show significant differences among the 4 diets $(P>0.05)$. The effect of dietary MP levels on milk yield was more pronounced during the latter experimental period (Figure 1).

Milk yield increased as the MP increased up to 9.7\% of DM (diet C), and then leveled off. This significant ( $P$ 


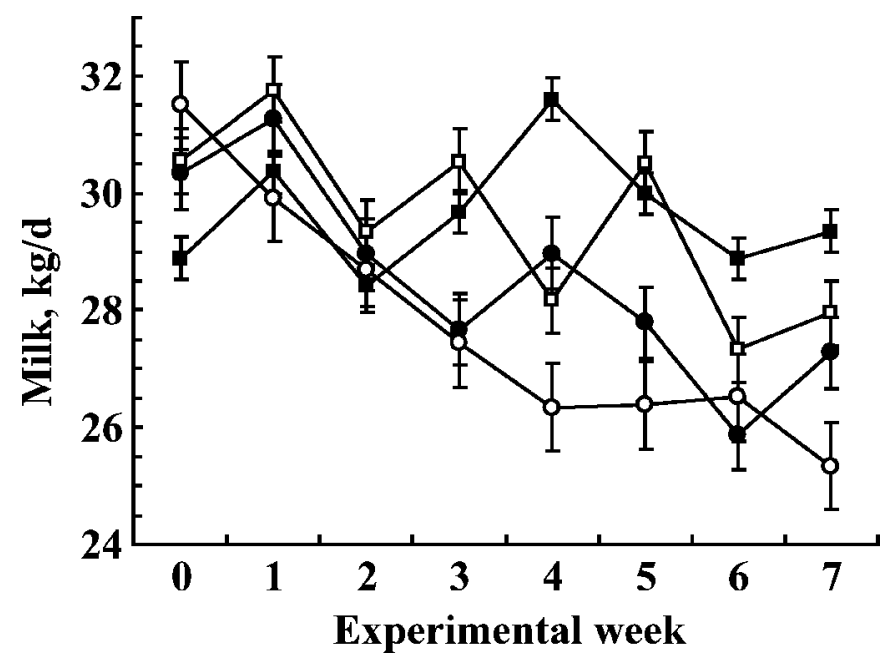

Figure 1. Milk yield of cows fed diets providing MP at $8.2 \%(\bigcirc)$, $8.9 \%(\bullet), 9.7 \%(\square)$, and $10.3 \%(\square)$ of DM. Bars indicate standard error.

$<0.05)$ curvilinear trend was consistent with others' observations that milk yield increased from 33.9 to 36.2 $\mathrm{kg} / \mathrm{d}$ with increasing MP from 8.1 to $10.2 \%$ of DM (Raggio et al., 2004), and that increasing the MP by $30 \%$ increased both the milk yield and milk protein yield (Metcalf et al., 1996; Wright et al., 1998). In contrast, previous reports also showed that milk yield did not increase when dietary protein was increased from 17.2 to $19.0 \%$ (Sannes et al., 2002), from 16.8 to $19.4 \%$ (Davidson et al., 2003), from 16.7 to $18.4 \%$ (Broderick, 2003), and from 15 to $18.7 \%$ (Groff and Wu, 2005). In this study, daily milk yield per cow was $2.6 \mathrm{~kg} / \mathrm{d}$ higher with the highest MP level compared with the lowest MP level, equivalent to $1.2 \mathrm{~kg} / \mathrm{d}$ for every $1 \%$ unit increase in the MP content of the diet.

A strong polynomial regression was found between FCM and MP (Figure 2), and a second-degree curve was fitted to present the changes in FCM $(\mathrm{kg} / \mathrm{d})$ with increments in the MP level (\%):

$$
\mathrm{FCM}=-1.51 \mathrm{MP}^{2}+28.8 \mathrm{MP}-109\left(\mathrm{R}^{2}=0.985\right) .
$$

From the equation it may be estimated that the optimal MP content was at $9.54 \%$ for FCM production. Similarly, there was also a strong polynomial regression between the MP content and milk protein yield (Figure 2 ), with a maximum value at $9.65 \%$ of $\mathrm{DM}$, which was similar to the optimal level for FCM.

The MP in this study was defined as the total digestible net protein available to the animals for metabolism after digestion and absorption of the feed in the animals' digestive tracts. The optimal MP content obtained in this study (9.6\% of DM) was $11 \%$ lower than that $(10.3 \%$

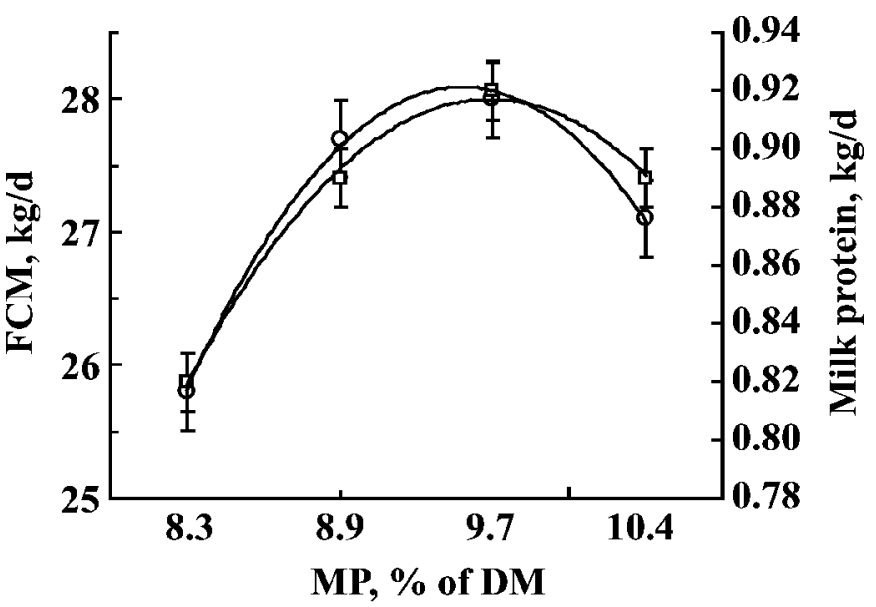

Figure 2. Relationship between FCM $(\bigcirc)$ or milk protein yield (MPY; $\square$ ) and content of MP. Fat-corrected milk (kg/d) vs. MP (\% of $\mathrm{DM}), \mathrm{FCM}=-1.51 \mathrm{MP}^{2}+28.8 \mathrm{MP}-109\left(\mathrm{r}^{2}=0.985\right) ; \mathrm{MPY}(\mathrm{kg} / \mathrm{d}) \mathrm{vs}$. $\mathrm{MP}\left(\%\right.$ of DM), MPY $=-0.0549 \mathrm{MP}^{2}+1.06 \mathrm{MP}-4.20\left(\mathrm{r}^{2}=0.999\right)$. Bars indicate standard error.

of DM) recommended by the NRC (2001), but was $9 \%$ higher than that $(8.9 \%$ of $\mathrm{DM})$ recommended by the AFRC (1993), and was 17\% higher than that (8.2\% of DM) in the CNSAPH (2000). The model from the NRC (2001) predicts protein yield using fixed efficiencies of conversion of MP supply for production (0.67), similar to that of the AFRC $(1993 ; 0.68)$ but $4.5 \%$ lower than that used in the CNSAPH (2000; 0.70). Moreover, the difference was not considered in requirements for maintenance between lactation and nonlactation or low and high dietary proteins in CNSAPH (2000) and AFRC (1993). These may account for the differences in MP levels between the different recommendations.

To further compare differences between the CNSAPH and NRC systems, the observed and the MP-predicted milk production (NRC, 2001) are shown in Figure 3. The slope of the regression $(0.70 \pm 0.061)$ was different $(P<0.05)$ from 1.0, indicating a significant linear bias. The mean milk production was overpredicted by 4.2 $\mathrm{kg} / \mathrm{d}(27.7 \mathrm{vs} .31 .9 \mathrm{~kg} / \mathrm{d})$, about $15 \%$ greater than the observed value.

\section{Efficiency of Utilization and Excretion of Dietary $\mathbf{N}$}

As the MP supply increased from 8.2 to $10.3 \%$, the protein conversion efficiency (milk protein:CP intake) decreased linearly (Table 3), in agreement with earlier research by Dinn et al. (1998). A recent review of studies in which AA were infused postruminally in dairy cows supports the concept that the transfer of incremental AA supply into milk protein diminishes as the supply approaches requirements, resulting in decreased effi- 


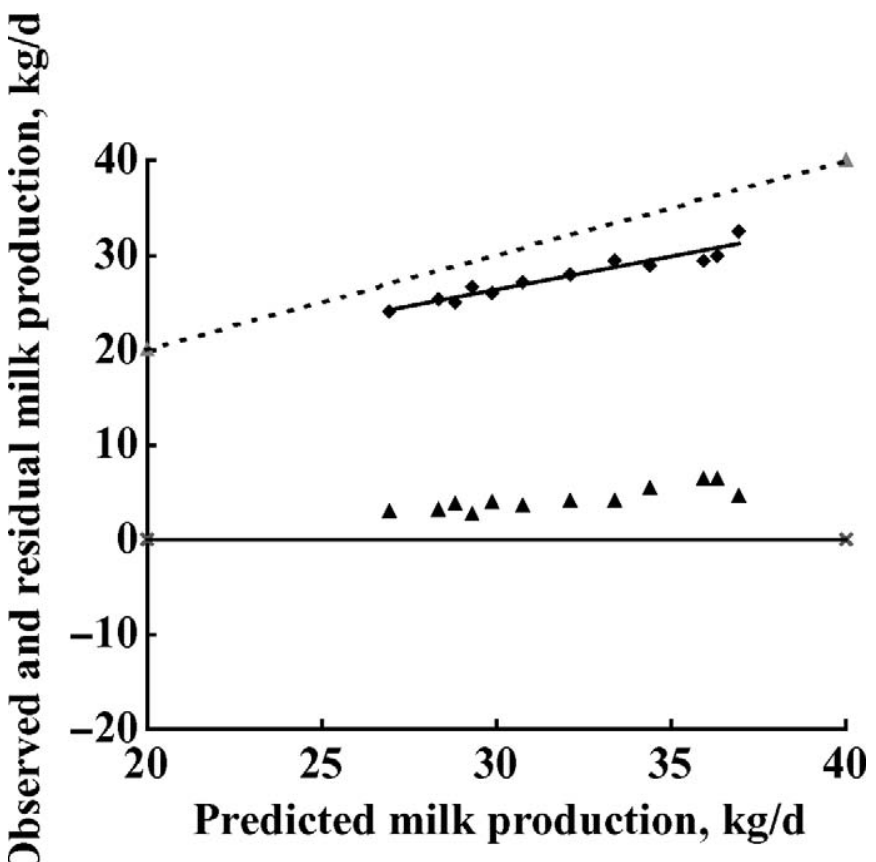

Figure 3. Predicted vs. observed milk production for cows $(\diamond)$ in the present study and residual milk production (observed minus predicted; $\mathbf{\Delta})$. Predicted milk production was calculated based on the MP intake as in the NRC (2001) model. The slope of the regression (solid line) was $0.70( \pm 0.061)$ and differed $(P<0.05)$ from the expected slope of 1.0 (dashed line) in the absence of a linear prediction bias.

ciency (Doepel et al., 2004). In the current study, although the amount of $\mathrm{N}$ transferred into milk was improved by an increased supply of MP, the efficiency of conversion of ingested $\mathrm{N}$ into milk (milk protein:CP intake) decreased when the MP content increased. Similar results were also observed by Wright et al. (1998), Castillo et al. (2001), and Raggio et al. (2004). This implies that an increase in the dietary MP level may result in an increased output of $\mathrm{N}$ to the environment.

The concentrations of urea $\mathrm{N}$ in milk and plasma were closely associated (Table $3, R^{2}=0.87$ ), consistent with Baker et al. (1995), Campanile et al. (1998), and
Broderick and Clayton (1997). With an increase in the MP level, urea N concentrations increased linearly in serum, urine, and milk $(P<0.05)$. When daily urinary $\mathrm{N}$ (UN) excretion was calculated using the equation developed for Chinese Holstein cows by Zhai et al. (2005):

$$
\mathrm{UN}(\mathrm{g} / \mathrm{d})=11.42 \times \mathrm{MUN}(\mathrm{mg} / \mathrm{dL})+41.93
$$

the UN was equal to $154,168,190$, and $260 \mathrm{~g} / \mathrm{d}$ for $\operatorname{diets} \mathrm{A}, \mathrm{B}, \mathrm{C}$, and $\mathrm{D}$, respectively. The proportion of the estimated UN in the $\mathrm{N}$ intake was $38,38,39$, and $50 \%$ for $\operatorname{diets} \mathrm{A}, \mathrm{B}, \mathrm{C}$, and $\mathrm{D}$, respectively. The UN was increased by $25 \%$ when dietary MP was supplied at the highest level (10.4\%). Obviously, part of the increased $\mathrm{N}$ intake from a high supply of MP is lost in urine. Therefore, the optimal MP content should be based not only on milk production, but also on $\mathrm{N}$ excretion and associated environmental consequences.

\section{CONCLUSIONS}

Milk yield, milk protein yield, and milk protein percentage increased as the dietary MP increased up to $9.7 \%$ of DM, and then leveled off. Decreased efficiency of conversion of $\mathrm{N}$ into milk with increased $\mathrm{N}$ intake was consistent with increased concentrations of urea $\mathrm{N}$ in the urine, serum, and milk, which may result in high excretion of $\mathrm{N}$ into the environment. Therefore, the MP requirement determined by the NRC (2001) is too high for Chinese Holstein cows, whereas the current CNSAPH (2000) guideline seems to be too low to fulfill the requirement for Chinese Holstein lactating cows.

\section{ACKNOWLEDGMENTS}

The authors gratefully acknowledge Ge Chu-tian, Yue Han, and all staff of the Hangzhou Zhengxing Animal Industry Company for their assistance in animal feeding and care.

Table 3. Effect of levels of MP on $\mathrm{N}$ utilization efficiency and urea $\mathrm{N}$ concentration in serum, urine, and milk

\begin{tabular}{lccccccc}
\hline & & & & & & \multicolumn{2}{c}{$P^{1}$} \\
\cline { 3 - 8 } Item & Diet A & Diet B & Diet C & Diet D & SEM & L & Q \\
\hline N conversion ${ }^{2}$ & $0.330^{\mathrm{a}}$ & $0.319^{\mathrm{ab}}$ & $0.302^{\mathrm{b}}$ & $0.278^{\mathrm{c}}$ & 0.0501 & $<0.01$ & 0.20 \\
Urea N concentration, mg/dL & & & & & & & \\
Serum & $8.6^{\mathrm{c}}$ & $11.8^{\mathrm{b}}$ & $14.7^{\mathrm{a}}$ & $15.7^{\mathrm{a}}$ & 0.52 & $<0.01$ & 0.10 \\
Urine & $4690^{\mathrm{b}}$ & $535.2^{\mathrm{ab}}$ & $718.1^{\mathrm{a}}$ & $712.8^{\mathrm{a}}$ & 4.39 & $<0.01$ & 0.30 \\
Milk & $9.8^{\mathrm{c}}$ & $11.0^{\mathrm{bc}}$ & $13.0^{\mathrm{b}}$ & $19.1^{\mathrm{a}}$ & 0.55 & $<0.01$ & $<0.01$ \\
\hline
\end{tabular}

${ }^{\mathrm{a}-\mathrm{c}}$ Means within same row with different superscripts differ $(P<0.05)$.

${ }^{1} \mathrm{~L}=$ linear; $\mathrm{Q}=$ quadratic.

${ }^{2}$ Milk protein yield:CP intake. 


\section{REFERENCES}

Agricultural and Food Research Council (AFRC). 1993. Energy and Protein Requirements of Ruminants: An Advisory Manual Proposed by the AFRC Technical Committee on Responses to Nutrients. CAB International, Wallingford, UK.

AOAC. 1990. Official Methods of Analysis. 15th ed. Vol. 1. Assoc. Offic. Anal. Chem., Arlington, VA.

Baker, L. D., J. D. Ferguson, and W. Chalupa. 1995. Responses in urea and true protein of milk to different protein feeding schemes for dairy cows. J. Dairy Sci. 78:2424-2434.

Broderick, G. A., and M. K. Clayton. 1997. A statistical evaluation of animal and nutritional factors influencing concentration of milk urea nitrogen. J. Dairy Sci. 80:2964-2971.

Broderick, G. A. 2003. Effects of carrying dietary protein and energy levels on the production of lactating dairy cows. J. Dairy Sci. 86:1370-1381.

Campanile, G., C. De Filippo, R. Di Palo, W. Taccone, and L. Zicarelli. 1998. Influence of dietary protein on urea levels in blood and milk of buffalo cows. Livest. Prod. Sci. 55:135-143.

Castillo, A. R., E. Kebreab, D. E. Beever, J. H. Barbi, J. D. Sutton, H. C. Kirby, and J. France. 2001. The effect of protein supplementation on nitrogen utilization in lactating dairy cows fed grass silage diets. J. Anim. Sci. 79:247-253.

Chinese National Station of Animal Production and Health (CNSAPH). 2000. Nutrient Requirements and Feeding Standards of Dairy Cattle. 2nd rev. China Agricultural University Press, Beijing, China.

Clark, J. H., T. H. Klusmeyer, and M. R. Cameron. 1992. Symposium: Nitrogen metabolism and amino acid nutrition in dairy cattle: Microbial protein synthesis and flows of nitrogen fractions to the duodenum of dairy cows. J. Dairy Sci. 75:2304-2323.

Davidson, S., B. A. Hopkins, D. E. Diaz, S. M. Bolt, C. Brownie, V. Fellner, and L. W. Whitelow. 2003. Effects of amounts and degradability of dietary protein on lactation, nitrogen utilization and excretion in early lactation Holstein cows. J. Dairy Sci. $86: 1681-1689$.

Dinn, N. E., J. A. Shelford, and L. J. Fisher. 1998. Use of the Cornell Net Carbohydrate and Protein System and rumen-protected lysine and methionine to reduce nitrogen excretion from lactating dairy cows. J. Dairy Sci. 81:229-237.

Doepel, L., D. Pacheco, J. J. Kennelly, M. D. Hanigan, F. P. Lppz, and H. Lapierre. 2004. Milk protein synthesis as a function of amino acid supply. J. Dairy Sci. 87:1279-1297.

Gill, J. L. 1978. Design and Analysis of Experiments in the Animal and Medical Sciences. Vol. 1. The Iowa State Press, Ames.

Groff, E. B., and Z. Wu. 2005. Milk production and nitrogen excretion of dairy cows fed different amounts of protein and carrying proportions of alfalfa and corn silage. J. Dairy Sci. 88:3619-3632.

Higginbotham, G. E., M. Torabi, and J. T. Huber. 1989. Influence of dietary protein concentration and degradability on performance of lactating cows during hot environmental temperature. J. Dairy Sci. 72:2554-2564.
Huston, J., R. Pitt, R. Koelsch, J. Houser, and R. Wagenet. 1998. Improving dairy farm sustainability. II: Environmental losses and nutrient flows. J. Prod. Agric. 11:233-239.

Laporte, M. F., and P. Paquin. 1999. Near-infrared analysis of fat, protein, and casein in cow's milk. J. Agric. Food Chem. 47:2600-2605.

Metcalf, J. A., D. Wray-Cahen, E. E. Chettle, J. D. Sutton, D. E. Beever, L. A. Crompton, J. C. MacRae, B. J. Bequette, and F. R. C. Backwell. 1996. The effect of dietary crude protein as protected soybean meal on mammary metabolism in the lactating dairy cow. J. Dairy Sci. 79:603-611.

NRC. 2001. Nutrient Requirements of Dairy Cattle. 7th ed. Natl. Acad. Sci., Washington, DC.

Raggio, G., D. Pacheco, R. Berthiaume, G. E. Lobley, D. Pellerin, G. Allard, P. Dubreuil, and H. Lapierre. 2004. Effect of level of metabolizable protein on splanchnic flux of amino acids in lactating dairy cows. J. Dairy Sci. 87:3461-3472.

Rahmatullah, M., and T. R. Boyde. 1980. Improvements in the determination of urea using diacetyl monoxime; methods with and without deproteinisation. Clin. Chim. Acta 107:3-9.

Sannes, R. A., M. A. Messman, and D. B. Vagnoni. 2002. Form of rumen degradable carbohydrate and nitrogen on microbial protein synthesis and protein efficiency of dairy cows. J. Dairy Sci. 85:900-908

Santos, F. A. P., and J. T. Huber. 1995. Effects of rumen undegradable protein on dairy cow performance: A 10 year literature review. J. Dairy Sci. 78(Suppl. 1):293. (Abstr.)

Santos, F. A., J. E. Santos, C. B. Theurer, and J. T. Huber. 1998 Effects of rumen-undegradable protein on dairy cow performance: A 12 year literature review. J. Dairy Sci. 81:3182-3213.

SAS Institute. 2000. SAS User's Guide. Statistics, Version 8.01. SAS Inst., Inc., Cary, NC.

Tamminga, S. 1992. Nutrition management of dairy cows as a contribution to pollution control. J. Dairy Sci. 75:345-357.

Valadares, R. F. D., G. A. Broderick, S. C. Valadares Filho, and M. K. Clayton. 1999. Effect of replacing alfalfa silage with high moisture corn on ruminal protein synthesis estimated from excretion of total purine derivatives. J. Dairy Sci. 82:2686-2696.

Van Horn, H. H., A. C. Wilkie, W. J. Powers, and R. A. Norstedt. 1994. Components of dairy manure management systems. J. Dairy Sci. 77:2008-2030.

Van Soest, P. J., J. B. Bobertson, and B. A. Lewis. 1991. Methods of dietary fiber, neutral detergent fiber, and nonstarch polysaccharides in relation to animal nutrition. J. Dairy Sci. 74:3583-3597.

Varel, V. H., J. A. Nienaber, and H. C. Freetly. 1999. Conservation of nitrogen in cattle feedlot waste with urease inhibitors. J. Anim. Sci. 77:1162-1168.

Wright, T. C., S. Moscardini, P. H. Luimes, P. Susmel, and B. W. McBride. 1998. Effects of rumen-undegradable protein and feed intake on nitrogen balance and milk protein production in dairy cows. J. Dairy Sci. 81:784-793.

Zhai, S. W., J. X. Liu, and Y. Ma. 2005. Relation between milk urea content and nitrogen excretion from lactating cows. Acta Agric. Scand. A 55:113-115. 